\title{
ANALISIS PDRB KABUPATEN KEBUMEN \\ SEKTOR PERDAGANGAN, HOTEL DAN RESTORAN ATAS DASAR HARGA BERLAKU TAHUN 2008-2013
}

\author{
Yulianto \\ Dosen Akademi Pariwisata "BSI Yogyakarta" \\ Yulianto.ylt@bsi.ac.id
}

\begin{abstract}
Gross Regional Domestic Product is as the amount of value added (add value) that are generated by the entire production unit or in a region or the entire amount is the value of final goods and services produced by the economy of the entire unit within a region in a given period, either on the basis of rates in force or on the basis of constant prices. One GRP District of Kebumen is a sector of trade, hotels and restaurants which is an important part of the calculation and the increasing economic growth each year has increased, although not significantly.

On the trade sector, the hotel and restaurant viewed from the results of analysis calculation on persamanan trend for certain years have elevated the quality of the year 2008 amounting to 583, 253.02 in 2009 amounted to 651, 473.61, then increment level trends in $2010719,694.20$, while for the year 2011 for the highest rate of increase in trends, namely of 856, 135.38, then in 2012 has increased the trend 355.97 924, and 2013 for trends 992 , 576.56 .
\end{abstract}

The result of the analysis of the Gross Domestic Product has increased from Kebumen Regency, trade, hotels and restaurants on the basis of the applicable rates in 20082013.

Keywords: PDRB, Trade, Hotels and Restaurants

\section{PENDAHULUAN}

Salah satu indikator penting untuk mengetahui kondisi ekonomi disuatu wilayah dalam suatu periode tertentu adalah PDRB. PDRB untuk menentukan strategi dan kebijaksanaan pembangunan perekonomian baik untuk mengevaluasi memperbaiki dan melanjutkan pembangunan perekonomian dimasa yang akan datang.

Untuk mengetahui tingkat pertumbuhan masyarakat suatu wilayah (region) disajikan pendapatan regional secara berkala yang dapat digunakan sebagai bahan perencanaan pembangunan regional/ daerah khususnya dibidang ekonomi. Angka-angka Pendapatan Regional atau Produk Domestik Bruto (PDRB) memerlukan suatu indikator berupa data agregat yang dapat dipakai untuk mengukur tingkat pertumbuhan ekonomi suatu daerah. Disamping itu PDRB juga dapat dipakai sebagai bahan evaluasi dari hasil kegiatan pembangunan ekonomi yang telah dilaksanakan baik oleh pemerintah maupun non pemerintah.

Pertumbuhan ekonomi suatu masyarakat juga dapat digunakan income per capita yang merupakan hasil bagi antara pendapatan regional disuatu wilayah dengan jumlah penduduk pada wilayah tersebut. Pelaksanaan otonomi daerah diperlukan sumber daya dan dana yang memadai termasuk instrumen pembangunan berupa data dan informasi yang cepat, tepat, lengkap dan akurat sebagai dasar pengambilan keputusan. Ketepatan, kecermatan dan ketepatan informasi tentang kondisi suatu 
daerah, baik kualitatif maupun kuantitatif dibidang sosial, ekonomi, pariwasata dan lain-lain, menunjukan kesiapan daerah dalam menjalankan proses perekonomian.

Perencanaan dan evaluasi pembangunan perekonomian sangat memerlukan informasi perkembangan ekonomi makro adalah Produk Domestik Bruto sebagai strategi dan kebijaksanaan pembangunan perekonomian yang telah diambil dapat dievaluasi kembali dengan tujuan diperbaiki atau dilanjutkan pada masa yang akan datang.

Untuk mengetahui tingkat perkembangan pendapatan penduduk suatu daerah secara rata-rata dengan menggunakan angka pendapatan perkapita yaitu hasil bagi antara pendapatan regional dengan jumlah penduduk pertengahan tahun yang sama. Untuk pendapatan perkapita tahun 2013 sebesar 7.508.797,11 rupiah atau tumbuh 11,24 persen dibanding tahun 2012 yang tercatat sebesar 6.750.115,81 rupiah menurut harga berlaku, juga dapat diketahui ratarata pertumbuhan pendapatan per Kapita di Kabupaten Kebumen selama enam tahun terakhir ( 2008 - 2013 ) sebesar 11,23 persen atas dasar harga berlaku dan 4,42 persen atas dasar harga konstan 2000.

Salah satu sektor pada Produk Domestik Bruto adalah sektor perdagangan, hotel dan restoranyang cukup besar dalammeningkatan PDRB Kabupaten Kebumen Sehingga dapat dianalisa pada sektor tersebut. Trend kenaikan pada sektor perdagangan, hotel dan restoran diperkirakan akan meningkat setiap tahunnya.

\section{LANDASAN TEORI}

Untuk memperdalam dan menunjang tujuan penelitian diperlukan landasan teori sebagai dasar untuk karya ilmiah ini :

\section{Produk Domesti Bruto Kabupaten Kebumen}

Produk Domestik Regional Bruto (
PDRB) didefinisikan sebagai jumlah nilai tambah ( add value ) yang dihasilkan oleh seluruh unit produksi atau usaha didalam suatu wilayah atau merupakan jumlah seluruh nilai barang dan jasa akhir yang dihasilkan oleh seluruh unit ekonomi disuatu wilayah dalam jangka waktu tertentu, baik atas dasar harga berlaku maupun atas dasar harga konstan. Konsep Produk Domestik Regional Bruto (PDRB) dapat pula diturunkan menjadi Produk Domestrik Regional Netto (PDRN) yaitu cara mengeluarkan atau mengurangkan faktor penyusutan atau depresiasi dari nilai tambah Bruto.

\section{Perdagangan}

Dilihat dari nilai tambah atas dasar harga konstan perdagangan merupakan penghitungan nilai tambah pada sub sektor perdagangan yang meliputi perdagangan besar dan eceran yang dilakukan dengan pendekatan arus barang yaitu dengan cara menghitung besarnya nilai komoditi pertanian, pertambangan dan penggalian, industri dan komoditi impor yang diperdagangkan.

\section{Pengertian Hotel}

Menurut Surat Keputusan Menteri Pariwisata, Pos dan Telekomunikasi No. KM 37/PW.340/MPPT-86 dalam buku Agus Sulastiyono (2007:3), Hotel adalah suatu jenis akomodasi yang mempergunakan sebagian atau seluruh bangunan untuk menyediakan jasa penginapan, makanan dan minuman serta jasa penunjang lainnya bagi umum yang dikelola secara komersial. Selanjutnya dalam Peraturan Pemerintah Republik Indonesia Nomor 67 tahun 1996 tentang Penyelenggaraan Kepariwisataan Republik Indonesia pada pasal 61 dinyatakan bahwa "Pelayanan pokok usaha hotel yang harus disediakan sekurang-kurangnya harus meliputi penyediaan kamar tempat menginap, penyediaan tempat dan pelayanan makan dan minum, penyediaan pelayanan 
pencucian pakaian/binatu dan penyediaan fasilitas lainnya. Peraturan Pemerintah tersebut secara implisit memberikan definisi mengenai kata "hotel".

Menurut SK. Menhub. RI. No. PM 10 / PW.391 / Phb 77 dalam buku Bambang Sujatno (2006:29), Hotel adalah suatu bentuk akomodasi yang dikelola secara komersial, disediakan bagi setiap orang untuk memperoleh pelayanan penginapan berikut makan dan minum.Menurut SK. Menparpostel Nomor KM 34/HK 103/ MPPT- 87 dalam buku Wisnu HS (2006:4), Hotel adalah suatu jenis akomodasi yang mempergunakan sebagian atau seluruh bangunan untuk menyediakan jasa pelayanan penginapan, makan, dan minun serta jasa lainnya bagi umum, yang dikelola secara komersial serta memenuhi ketentuan persyaratan yang di tetapkan di dalam keputusan pemerintah.

\section{Pengertian Restoran}

Menurut Arif (2005:31) Restoran merupakan industri yang tak terbatas, yaitu industri yang melayani makanan dan minuman kepada semua orang yang jauh dari rumahnya maupun yang dekat dari rumahnya.

Menurut Marsum (2005:8) dalam buku Restoran ada beberapa jenis restoran yaitu: Table D'hote Restaurant, A'la Carte Restaurant, Grill Room (Rotisserie), Dinning Room, Carvery, Pizzeria, Fish and Chip Restaurant, Cafeteria atau Café, Pan Cake House atau Creperie, Coffee Shop atau Brasserie, Pub, Canteen, Snack Bar atau Café atau Milk Bar, Continental Restaurant, Night Club atau Super Club, Distcotheque, Family Type Restaurant, Inn Tavern, Main Dining Room, Terrace Restaurant, Gourmet Restoran, Specialty Restaurant.

\section{Teori pertumbuhan ekonomi :}

Teori pertumbuhan F.List dalam bukunya Siagian (2004) adalah

Perkembangan ekonomi sebesarnya tergantung pada peranan pemerintah, organisasi swasta dan lingkungan kebudayaan. Perkembangan akan terjadi jika masyarakat ada kebebasan dalam berorganisasi politik dan kebebasan perseorangan. Perkembangan ekonomi menurutnya 5 tahap, tahap primitif, beternak, pertanian, industri pengolahan dan perdagangan.

Teori pertumbuhan Karl Bucher dalam bukunya Siagian (2004) adalah

Pertumbuhan ekonomi melalui tiga (3) tingkat yaitu : Produksi untuk kebutuhan sendiri, Perekonomian kota, dimana pertukaran sudah meluas dan perekonomian nasional dimana peranan pedagangpedadang tampak makin kecil.

Teori pembangunan W.W Rostow dalam bukunya Siagian (2004) adalah

Pada economic journal kemudian dikembangkan The Stages of Economic Growth(1990) proses pembangunan ekonomi dibedakan 5 tahap pembangunan yaitu (1). The tradisional society. (2). The precondition for take off. (3). The take off. (4). The drive to naturity (5). The age of hight mass comsumption.

Dasar tahap pembangunan ekonomi menjadi lima tahap tersebut adalah karakteristik perubahan keadaan ekonomi, sosial dan politik yang terjadi. Pembangunan ekonomi atau proses transformasi suatu masyarakat tradisional menjadi masyarakat modern merupakan suatu proses yang multidimensional.

\section{Pembangunan ekonomi daerah}

Proses pembangunan ekonomi daerah kaya dan daerah miskin secara relatif sukar dikembangkan faktor-faktor tersebut. Trickling down effect and backwash effect, bila perbedaan antara kedua daerah semakin 
menyempit berarti terjadi imbas yang baik (trickling down effect sedangkan jika perbedaan antara kedua daerah semakin jauh berarti terjadi proses pengangkutan (polarization effect). Pembangunan ekonomi daerah berorientasi pada proses merupakan perubahan yang melibatkan proses formasi pembentukan-pembentukan institusiinstitusi baru, pembangunan industri alternatif, perbaikan kapasitas pekerja yang ada untuk menghasilkan produk yang lebih baik, identifikasi pasar baru, transfer ilmu pengetahuan dan membina perusahaan baru.

\section{Kebijakan Pemerintah Daerah}

Peran pemerintah daerah saat ini sama dengan pemerintah pusat meningkatan ekonominya masing-masing, pemerintah daerah dituntut dapat berkreasi dalam menangani permasalahan iklim investasi melalui berbagai kebijakan yang mendukung terciptanya usaha yang sehat. Kebijakan pemerintah daerah untuk meningkatan investasi dipengaruhi oleh instrumen kebijakan, pelaksanaan dan pengendalian terhadap pelaksanaan kebijakan tersebut. Adapun kebijakan peraturan perundangan dalam kerangka regulasi, pengelolaan belanja daerah, penyediaan pelayanan terpadu, pemberdayaan usaha mikro, kecildan menengah dan koperasi dan pengembangan sektor unggulan memalu kluster industri.

\section{Daya Saing Daerah}

Daya saing daerah mempunyai arti sama dengan daya saing nasioanl, hal ini suatu daerah harus mampu bersaing dengan daerah lain dalam memproduksi dan memasarkan barang dan jasa. Menurut World Economic Forum (WEF) daya saing adalah kemampuan suatu perekonomian Nasional untuk mencapai pertumbuhan ekonomi yang tinggi dan berkelanjutan. Institute of Manajemen and Development (IMD) daya saing sebagai kemampuan suatu negara, untuk menciptakan nilai tambah dalam rangka menambah kekayaan nasional dengan cara mengelola aset dan proses daya tarik dan agresivitas, globalitas dan proksimitas.

\section{Singkronisasi Kebijakan Pusat dan Daerah}

Singkronisasi Kebijakan Pusat dan Daerah diperlukan berbagai dukungan berupa penciptaan iklim usaha usaha dan kondusif, kapasitas infrastruktur yang memadai, intermedia lembaga keuangan, tata pemerintahan yang baik serta keamanan dan ketertiban. Dalam jangka panjang daya saing nasional ditentukan oleh dukungan sumber daya manusia berkualitas dan diperlukan peningkatan investasi disiapkan dan dilaksanakan oleh pemerintah pusat dan pemerintah daerah secara konsisten dan sinergis.

\section{METODE PENELITIAN}

Dalam membuat karya ilmiah ini, metodelogi yang digunakan menurut Kusmayadi (2004; 29) menyatakan bahwa metode penelitian deskriptif adalah penelitian yang berusaha mendeskriptifkan, menggambarkan/melukiskan fenomena atau hubungan antara fenomena yang diteliti dengan sistematis, faktual dan akurat. Melalui metode ini, mengungkapakan data aktual, mengumpulkan dan menganalisis berdasarkan teori-teori yang sesuai dengan permasalahan yang ada. Penelitian ini menggunakan analisis Trend, data yang diperoleh adalah data sekunder yang diperoleh dari Bappeda Kabupaten Kebumen dan Biro Pusat Statistik data pada sektor perdagangan, hotel dan restoran atas dasar harga berlaku pada tahun 2008-2013.

\section{PEMBAHASAN}

\section{Tahun Dasar}

Produk Domestik Regional Bruto (PDRB) Kabupaten Kebumen dihitung 
dengan menggunakan harga berlaku yaitu harga pada tahun tertentu misal 2013 (yang kemudian disebut dengan PDRB atas dasar harga berlaku tahun 2013) dan dihitung dengan harga pada tahun dasar 2000 (yang kemudian disebut dengan PDRB atas dasar harga konstan tahun 2000).

Sejak tahun 2005 secara nasional penghitungan PDRB atas dasar harga konstan menggunakan tahun dasar baru yaitu Tahun 2000. Penggantian tahun dasar sudah dilakukan beberapa kali yaitu penggantian tahun dasar dari tahun dasar

1975 menjadi tahun dasar 1983, dan dari tahun dasar 1983 menjadi tahun dasar 1993. Hal itu dilakukan untuk keseragaman penghitungan PDRB sehingga dimungkinkan dilakukan perbandingan pertumbuhan ekonomi antar daerah maupun antar waktu.

Perkembangan teknologi dan perekonomian merupakan dua hal yang saling mempengaruhi dan telah mengakibatkan perubahan struktur secara terus menerus. Krisis ekonomi yang berdampak pada perubahan struktur perekonomian sehingga penggunaan tahun dasar 1993 (sudah 10 tahun lebih) tidak reprensentative lagi untuk digunakan sebgai tahun dasar penghitungan laju pertumbuhan ekonomi.

Perserikatan Bangsa-Bangsa (PBB) yang tertuang dalam buku Sistem Neraca Nasional dinyatakan bahwa estimasi PDB/PDRB atas dasar harga konstan sebaiknya dimuktahirkan secara periodik dengan menggunakan tahun referensi yang berakhiran 0 atau 5. dimaksudkan agar besaran angka-angka PDB/PDRB dapat saling diperbandingkan antara Negara/ propinsi/ Kabupaten/Kota dan antar waktu guna keperluan analisis kinerja perekonomian Nasional atau Wilayah.

Tahun dasar penghitungan PDB/ PDRB dari tahun 1993 ke tahun dasar baru menjadi perlu dilakukuan agar hasil estimasi
PDB/PDRB menjadi realistis dan mampu memberikan gambaran yang jelas terhadapa fenomena pergeseran struktur produksi lintas sektor.

Tahun dasar dianggap reprensentative untuk mengukur laju pertumbuhan ekonomi adalah tahun 2000 karena tahun tersebut dianggap sebagai tahun yang relatif stabil setelah krisis ekonomi 1997/1998. Pada tahun 2000 perekonomian Indonesia tumbuh sebesar 4,92 persen dan inflasi sebesar 9,35 persen, kabupaten kebumen mengalami pertumbuhan 4,67 persen dan inflasi 8,49 persen. Ini merupakan proses pemulihan setelah keterpurukan akibat krisis ekonomi yang membuat PDRB Jawa Tengah merosot sampai pada tingkat minus 13,05 persen tahun 1998, dengan inflasi mencapai 52,36 persen ditahun tersebut.

\section{Perkembangan PDRB Kebumen}

PDRB Kabupaten Kebumen Atas Dasar Harga Berlaku dan Harga Konstan 200 Serta Perkembangannya Di Kabupaten Kebumen : Tahun 2006 - 2013

Tabel : 1

PDRB atas Dasar Harga Berlaku

\begin{tabular}{|c|c|c|}
\hline \multirow{2}{*}{ Tahun } & \multicolumn{2}{|c|}{$\begin{array}{c}\text { PDRB Atas Dasar } \\
\text { HargaBerlaku }\end{array}$} \\
\cline { 2 - 3 } & $\begin{array}{c}\text { Jumlah } \\
\text { (Juta Rupiah) }\end{array}$ & $\begin{array}{c}\text { Perkembangan } \\
\text { (\%) }\end{array}$ \\
\hline 2006 & $4.082 .249,01$ & 195,94 \\
\hline 2007 & $4,568.870,87$ & 219,29 \\
\hline 2008 & $5.305 .932,01$ & 254,67 \\
\hline 2009 & $5.855 .355,63$ & 281,04 \\
\hline 2010 & $6.484 .243,60$ & 311,23 \\
\hline 2011 & $7.122 .249,81$ & 341,85 \\
\hline 2012 & $7.911 .378,74$ & 379,72 \\
\hline 2013 & $8.835 .316,23$ & 424,07 \\
\hline
\end{tabular}

Sumber: BPS Kabupaten Kebumen 
Berdasarkan tabel diatas menjelaskan bahwa nilai PDRB Kabupaten Kebumen Jawa Tengah tahun 2013 atas dasar harga berlaku sebesar 8.835.316,23 juta rupiah. Sehingga dalam kurun waktu 5 tahun (tahun 2006-2013). PDRB Kabupaten Kebumen atas dasar harga berlaku mengalami kenaikan 1,19 kali. Hal ini menunjukan bahwa secara secara agregat produksi barang dan jasa di Kabupaten Kebumen setelah tahun 2000 menunjukan kenaikan dari tahun ke tahun.

\section{Analisis Tren PDRB Sektor Perdagangan, Hotel dan Restoran}

Di dalam mengintreprestasikan hipotesis tentang perkembangan trend sektor Perdagangan, Hotel dan Restotan selama kurun waktu enam (6) tahun dari 2008-2013 di Kabupaten Kebumen Jawa Tengah.

\section{Tabel :2}

PDRB Kabupaten Kebumen Sektor Perdagangan, Hotel \& Restoran Atas Dasar Harga Berlaku Tahun 2008 - 2013 (Jutaan Rupiah)

\begin{tabular}{|l|l|c|}
\hline Tahun & \multicolumn{1}{|c|}{$\begin{array}{c}\text { Sektor } \\
\text { Perdagangan, } \\
\text { Hotel dan } \\
\text { Restoran }\end{array}$} & Trend \\
\hline 2008 & $58,178.15$ & $583,253.02$ \\
\hline 2009 & $656,418.32$ & $651,473.61$ \\
\hline 2010 & $742,247.76$ & $719,694.20$ \\
\hline 2011 & $802,938.86$ & $856,135.38$ \\
\hline 2012 & $892,260.23$ & $924,355.97$ \\
\hline 2013 & $1,046,445.39$ & $992,576.56$ \\
\hline
\end{tabular}

Berdasarkan pada hasil perhitungan trend PDRB pada sektor perdagangan, Horel dan Restoran dari tahun 2008-2013 dapat diketahui persamaannya adalah :

$$
\mathrm{Y}^{1}=\mathrm{a}+\mathrm{bX}
$$

Dimana :

$$
\begin{aligned}
& \mathrm{a}=\frac{\Sigma Y}{n}=\frac{4,727,488.71}{6}=787,914.79 \\
& \mathrm{~b}=\frac{\Sigma X Y}{\Sigma x^{2}}=\frac{1,910,176.64}{28}=68,220.59
\end{aligned}
$$

Sehingga persamaan Trend adalah :

$Y^{1}=787,914.79+68,220.59 X$

$\mathrm{Y}^{1}$ adalah estimasi trend pada perdagangan, Hotel dan restoran di Kabupaten Kebumen pada tahun 2008 - 2013

$\mathrm{a}=787,914.79$ adalah nilai perdagangan, hotel dan restoran atas dasar harga berlaku tahun $2008-2013$

$\mathrm{b}=68,220.59$ adalah nilai tambahan perdagangan, horel dan restoran atas dasar harga berlaku tahun 2008 - 2013

Berdasarkan hasil perhitungan untuk mencari nilai trend pada sektor perdagangan, Hotel dan restoran untuk nilai trend mengalami peningkatan signifikan adalah pada tahun 2011.

\section{KESIMPULAN}

Untuk mengetahui tingkat pertumbuhan ekonomi masyarakat suatu wilayah (region) dapat di lihat dari Produk Domesti Regional Bruto (PDRB) yang merupakan indikator berupa data agregat yang dapat dipakai untuk mengukur tingkat pertumbuhan ekonomi suatu daerah. Salah satu sub/bagian dari PDRB adalah pada sektor perdagangan, hotel dan restoran hal ini didasarkan pada perhitungan atas dasar harga berlaku dari tahun 2008-2013.

Dari hasil analisis trend sektor perdagangan hotel dan restoran sejak tahun 2008 - 2013 menunjukan adanya perkembangan yang meningkat. Hal ini dilihat dari perubahan hasil estimasi trend yang meningkat, yaitu dari tahun 2008 sebesar 583,253.02, pada tahun 2009 menjadi sebesar 651,473.61, pada tahun 2010 menjadi sebesar 719,694.20, pada tahun 2011 menjadi sebesar 856,135.38, 
pada tahun 2012 menjadi sebesar 924,355.97 dan pada tahun 2013 menjadi sebesar $992,576.56$

Dari semua nilai perdagangan, hotel dan restoran terhadap Produk Domestik Regional Bruto rata-rata mengalami peningkatan setiap tahunnya.

\section{DAFTAR PUSTAKA}

Arif, Abdul Rahman. 2005. Pengantar Ilmu Perhotelan dan Restoran. Yogyakarta: Graha Ilmu.

Bataafi, Wisnu HS AL. 2006, Housekeeping Departement-Floor \& Public Area Job Description \& Standart Operation Procedure, Bandung Alfa Beta BPS, 2014, Laporan Produk Domestik Bruto Kabupaten Kebumen, Bappeda Kebumen

Kusmayadi, 2004; Metodelogi Penelitian, Jakarta, Gramedia

M1. Jhingan. 1991. Ekonomi Pembangunan dan Perencanaan, Penerbit Raja Gratindo, Jakarta

Marsum. 2005. Restoran dan Segala Permasalahannya. Yogyakarta: Andi Offset

Siagian. 1990. Ekonomi dalam cita-cita dan realita, Jakarta : PT. Citra Aditya Bakti, Jakarta

Sulastiyono, Agus. 2007, Teknik dan Procedur Divisi Kamar pada bidang Hotel. Bandung, Alfabeta

Sujatno.A.Bambang, 2006. Hotel Courtesy. Yogyakarta : Andi Offset 